\title{
Qualifying the Information Detected from Airborne Laser Scanning to Support Tropical Forest Management Operational Planning
}

\author{
Cristiano Rodrigues Reis ${ }^{1, *(\mathbb{C})}$, Eric Bastos Gorgens ${ }^{2, *} *$ (D) Danilo Roberti Alves de Almeida ${ }^{1}(\mathbb{D}$, \\ Carlos Henrique Souza Celes ${ }^{3}{ }^{-}$, Jacqueline Rosette ${ }^{4}$, Adriano Lima ${ }^{3}$, Niro Higuchi ${ }^{3}\left({ }^{(0)}\right.$, \\ Jean Ometto ${ }^{5}$, Reynaldo Campos Santana ${ }^{2}{ }^{-}$and Luiz Carlos Estraviz Rodriguez ${ }^{1}$
}

Citation: Reis, C.R.; Gorgens, E.B.; Almeida, D.R.A.d.; Celes, C.H.S.; Rosette, J.; Lima, A.; Higuchi, N.; Ometto, J.; Santana, R.C.; Rodriguez, L.C.E. Qualifying the Information Detected from Airborne Laser Scanning to Support Tropical Forest Management Operational Planning. Forests 2021, 12, 1724. http:// doi.org/10.3390/f12121724

Academic Editor: William W. Hargrove

Received: 21 October 2021

Accepted: 2 December 2021

Published: 7 December 2021

Publisher's Note: MDPI stays neutral with regard to jurisdictional claims in published maps and institutional affiliations.

Copyright: (c) 2021 by the authors. Licensee MDPI, Basel, Switzerland. This article is an open access article distributed under the terms and conditions of the Creative Commons Attribution (CC BY) license (https:// creativecommons.org/licenses/by/ $4.0 /)$.
1 Departamento de Ciências Florestais, Universidade de São Paulo, Campus "Luiz de Queiroz", Av. Pádua Dias, n¹1, Piracicaba 13418-900, Brazil; daniloraa@usp.br (D.R.A.d.A.); lcer@usp.br (L.C.E.R.)

2 Departamento de Engenharia Florestal, Universidade Federal dos Vales do Jequitinhonha e Mucuri, Campus JK, Rodovia MGT 367-Km 583, n 5.000, Alto da Jacuba, Diamantina 39100-000, Brazil; reynaldo.santana@ufvjm.edu.br

3 Laboratório de Manejo Florestal, Instituto Nacional de Pesquisas da Amazônia, Av. André Araújo, 2.936, Manaus 69060-000, Brazil; caiqueceles@gmail.com (C.H.S.C.); adrianolmf@gmail.com (A.L.); higuchi.niro@gmail.com (N.H.)

4 Department of Geography, Wallace Building, Swansea University, Singleton Park, Swansea SA2 8PP, UK; j.a.rosette@swansea.ac.uk

5 Impacts, Adaptation and Vulnerability Division, National Institute for Space Research (INPE), Av. dos Astronautas, 1758, São José dos Campos 12227-010, Brazil; jean.ometto@inpe.br

* Correspondence: cristiano.reis@usp.br (C.R.R.); eric.gorgens@ufvjm.edu.br (E.B.G.)

\begin{abstract}
Background: Forests throughout the world are managed to fulfil a range of commercial and ecosystem services. The same applies to managed areas of the Amazon forest. We explore a method of sustainable forest management (SFM) which anticipates the result of processes of natural mortality of large, mature trees that could fall and damage their neighbors. Collecting all the information required for planning logging in the Brazilian Amazon is, currently, a hard, time-consuming and expensive task. (2) Methods: This information can be obtained more quickly, accurately and objectively by including airborne laser scanning (ALS) products in the operational plan. We used ALS point clouds to isolate emergent crowns from the canopy height model. Then, we performed field work to validate the existence of these trees, and to understand how many commercial trees (tree diameter $\geq 50 \mathrm{~cm}$ ) we identified by orienting the trees search through the emergent canopy model. (3) Results: We were able to detect 184 (54.4\%) trees from 338 field-recorded individuals in 20 plots (totaling 8 ha). Of the detected trees, 66 individuals were classified as having potential for commerce. Furthermore, 58 individuals presented the best stem quality for logging, which represents more than seven high quality commercial trees per hectare. The logistic regression showed that the effects that positively influence the emergent crown formation are strongly presented in the commercial species. (4) Conclusions: Using airborne laser scanning can improve the SFM planning in a structurally complex, dense and mixed composition tropical forest by reducing field work in the initial stages of management. Therefore, we propose that ALS operational planning can be used to more efficiently direct field surveys without the need for a full census.
\end{abstract}

Keywords: LiDAR; tropical rainforest; sustainable forest management; selective logging; emergent crowns

\section{Introduction}

Forest management planning demands several types of information related to the forest resources and their context. From the perspective of the forest resources, these comprise extent, quantity, composition, and resource condition [1]. Regarding the context, 
information on logging equipment characteristics, road layout, growing stock, silvicultural activities, terrain description, streamflow network are required. Forest management effectiveness depends on spatially explicit, accurate, and time-effective information.

Sustainable forest management (SFM) demands: (i) delineating relatively homogenous units based on characteristics such as tree species composition and stand structure [2], (ii) determining the best route to logging extraction to minimize soil and forest impacts [3] and (iii) reaching the easily derived indicators to monitor forest management activities [4,5]. SFM organizes actions that allow the ordering of production, implementing the selective logging practices [6,7]. In addition, an SFM plan must guarantee the forest production's continuity, avoid waste of wood, and certify the forest products resulting from the exploitation $[8,9]$. The accuracy and level of detail of the information has special limitations when forest management plans are implemented in areas that are not easily accessible [3].

Currently, an SFM plan relies on extensive and laborious forest inventory procedures, which contributes to increasing the business risk and cost $[3,10]$. The Brazilian law, for example, demands an extensive field data collection before any authorization is granted to cut a tree. Two main data collections are necessary. First, the forest inventory based on sample plots is implemented to support information to propose the SFM plan. After the approval of the SFM, it is necessary to get, annually, the approval to implement the operational activities. For that, a second field data collection is performed, recording all the trees (commercial and non-commercial) with diameter at breast height (DBH) greater than $50 \mathrm{~cm}$ presented in the annual production unit (also known as census). The census is the most important step for the operational planning since it not only quantifies the volume but also geolocates the trees, quantifies the commercial trees and records additional information such as stem quality, natural direction for tree falls, occurrence of stream flows, existence of gaps, presence of vines, and slope variation, among others.

Long-term analyses have shown that selective logging in areas with absence of other disturbances, such as fire and illegal logging, do not heavily affect biodiversity, and the effects on ecosystem processes are moderated [11]. Conversely, illegal and/or conventional logging is a key point of concern, since it threatens biodiversity conservation by deforestation $[9,12]$. Thus, individual tree information, including location and characterization, is fundamental to supporting the implementation of any SFM plan. Mapping those trees based on field work is a hard task in forests with large extent and sometimes under extreme conditions found in tropical forests (e.g., humidity, temperature, mosquitoes, etc.) [13].

To overcome those difficulties, a sequence of recent studies $[3,10,14-16]$ has shown that high-resolution products provided by airborne LiDAR (a.k.a. Airborne Laser ScanningALS) could be used to improve the SFM and operational planning. ALS generates data sets on large scales $[17,18]$, from which it is possible to detect and segment trees $[19,20]$. For instance, the linkage between spatial resolution (pixel size) and the concomitant objects that can be characterized (trees, stands) is well understood, with high spatial resolution data enabling single tree detection and analysis, and lower-spatial-resolution data sources enabling coarser stand-level (or broader) analyses [19,21]. Some individual tree detection and segmentation algorithms give the estimated position, size and shape of crowns [21]. This method preferentially detects trees that reach or grow above the mean forest canopy, i.e., the emergent crowns $[19,22]$. However, an important limitation to ALS consolidation as a resource for tropical forest planning is the qualitative comprehension of what ALS is capable of seeing regarding the forest.

Rather than supplanting existing approaches, ALS data can be integrated into current forest management processes [23] by providing information about the vertical structure that can be linked with the horizontal structure from field plots [19,24]. Studies have shown that ALS data can already provide information about the terrain characteristics [25], drainage network [26], forest characteristics [24,27], gaps dynamics [28,29], vegetation structure [30-32], coarse woody debris [33], tree life stage [34], diameter distribution [35,36], and others. However, ALS can only provide limited information related to forest composition, i.e., tree species [37]. 
In this paper, we used single tree locations detected by processing the ALS data, to run an inventory aiming to find and characterize the trees quantitatively and qualitatively in the field. To our knowledge, this is the first attempt to first qualify the information extracted by ALS data from a tropical forest.

Three goals are defined for this paper: (1) quantify and qualify (e.g., species, commercial interest, crown luminosity, stem quality and size) the detected/non-detected trees based on ALS processing; (2) from the detected trees, quantify the percentage of trees that match legal criteria for logging; (3) identify characteristics that influence detection/non-detection of the individual trees' characteristics.

\section{Materials and Methods}

The study was conducted at the Experimental Station for Tropical Silviculture (ZF2, Figure 1), at the National Institute of Amazon Research (INPA), located in Manaus (AM, Brazil). The area is located between the coordinates $02^{\circ} 33^{\prime} 43^{\prime \prime} \mathrm{S}$ to $02^{\circ} 40^{\prime} 23^{\prime \prime} \mathrm{S}$ and $60^{\circ} 07^{\prime} 15^{\prime \prime} \mathrm{W}$ to $60^{\circ} 13^{\prime} 31^{\prime \prime} \mathrm{W}$ and is composed of dense tropical forest of "terra-firme" with two main toposequences: valleys and plateaus [38]. The plateau is formed mainly of Yellow Oxisols, while valleys are formed by Hydromorphic Sandy [39]. The elevation above sea level ranges from 44 to 112 m (Figure 1A). The climate is classified as Af, according to Köppen, and is characterized by high temperature, precipitation and humidity year-round [40]. Temperatures vary between $23^{\circ} \mathrm{C}$ and $31^{\circ} \mathrm{C}$ and mean annual precipitation can reach $2078 \mathrm{~mm}$ [39]. The site where the study was conducted has mean canopy height of $30 \mathrm{~m}$, and the emergent trees can grow over $44 \mathrm{~m}$ tall [39] (Figure 1B).

We launched 20 field plots $\left(20 \times 200 \mathrm{~m}^{2}\right)$ in areas covered by four airborne laser scanning transects collected by the "Improving Biomass Estimation Methods for the Amazon" project [41] between 2016 and 2018. Within the area mapped by the transects, as criteria we selected four experimental sites, accessible by internal road and having previously been surveyed. Inside each site, the plots were randomly selected. The ALS campaign produced a point cloud using the LiDAR Harrier 68i sensor parameterized to allow a minimum density of 4 points. $\mathrm{m}^{-2}$. The horizontal and vertical accuracy was $\pm 1.0 \mathrm{~m}$ and \pm 0.5 , respectively. Each transect covers 375 ha $\left(12.5 \times 0.3 \mathrm{~km}^{2}\right)$ [42-45].

The ALS data were processed in the FUSION software version 3.80 [46] by removing outliers, homogenizing point cloud density, classifying the ground returns, creating the digital terrain model, normalizing the cloud, producing the canopy height model, and filtering the emergent canopy $(>35 \mathrm{~m})$. The outliers were removed by applying a search window of $20 \mathrm{~m}$ and considering as outliers all points outside the mean elevation \pm 3 standard deviation of returns within the window. Points were then classified as ground by the Kraus and Pfeifer algorithm [47,48] considering a window size of $8 \mathrm{~m}$ [25] and the standard parameter of FUSION [46]. We interpolated the ground points to create a digital terrain model (DTM) with 1-m pixel resolution. The canopy height model was created by interpolating the highest above ground points which are normalized with respect to the DTM [49]. The emergent canopy model was produced by applying a lower threshold of $35 \mathrm{~m}$ to the CHM. Then, we used the raster to vector function from QGIS to automatically create the crown polygons. Finally, to support the field campaign, we uploaded the vectorized crowns into the GNSS receiver.

During the field campaign we measured all trees with $\mathrm{DBH} \geq 50 \mathrm{~cm}$ in the 20 plots of $20 \mathrm{~m} \times 200 \mathrm{~m}$. The DBH was defined based on the threshold imposed by the Brazilian law on a SFM plan as the minimum allowable diameter size for logging [50]. For each tree, we recorded the following attributes: DBH, species, stem quality, canopy illumination, geographic coordinates, commercial interest and the correspondence to an ALS crown polygon. We identified the species based on previous botanical works developed in neighboring areas, and using the expertise of staff at INPA ZF-2 [51-53]. The commercial interest was based on the list provided by the Brazilian Forest Service (available in http:/ / snif.florestal.gov.br/pt-br/especies-florestais, accessed on 22 May 2019). Stem quality is divided into three levels according to percentage of commercial volume potential 
(straightness, defects, and bifurcations) [54]. The canopy illumination was defined visually as follows: if the canopy reached the highest layer in the forest and receives direct sunlight, it was classified as illuminated; the canopies presented in the mean canopy layer but with incidence of sunlight, they were classified as partially illuminated; lastly, trees under the mean canopy height were classified as shaded [54].
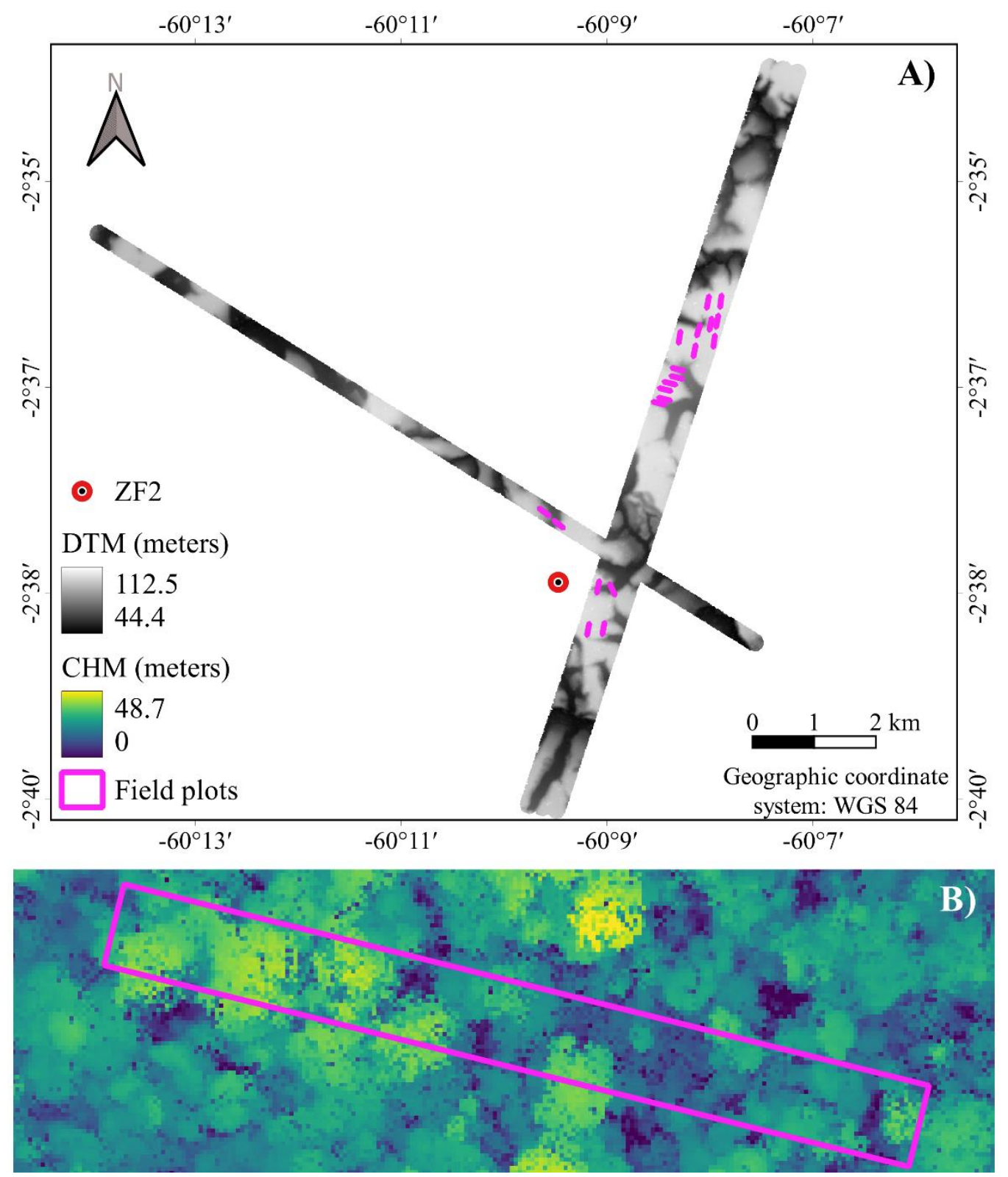

Figure 1. Study area is located at Experimental Station for Tropical Silviculture (ZF2), in Manaus, Amazonas State. (A) Digital terrain model (DTM) overlapped with the 20 field plots measured during the field work. (B) $20 \times 200 \mathrm{~m}^{2}$ field plot and the canopy height model (CHM).

We used a regular navigation GNSS (Garmim 76Cx), which is commonly used by the Brazilian foresters. The intention behind this decision is to see how common devices currently used to support forest management are able to detect the ALS extracted information. The GNSS collected coordinates combining two satellite systems (GPS and GLONASS) to reduce the geolocation error $[55,56]$. We also classified the DTM by applying the HillClimbing clustering algorithm with two clusters to split the data into valleys (floodplain) and plateaus [57]. 
We defined the trees' sociological position according to [58], from which the author classified the species into 10 different groups. From these 10 groups, one represents the pioneer species (group 7), one represents the emergent/climax species (group 8), and the remaining groups comprised the intermediary species. The field plots were processed to obtain the frequency and dominance, stem density and the importance value for each species (IVI = frequency, density and dominance combined). The field data were processed using the forestmangr package, developed for R [59].

Based on the correspondence to ALS-derived crown polygon (actual class) and to the crown illumination from the field emergent trees (detected class), we built a confusion matrix considering: class II-when a tree stem location matched an emergent canopy polygon (inside polygon) and had its canopy classified as totally or partially illuminated; class IS - when a tree stem matched an emergent canopy polygon (inside polygon) and had its canopy classified as shaded; class OI — when a tree did not match any emergent canopy polygon (outside polygon) and had its canopy classified as totally or partially illuminated; class OS - when a tree did not match any emergent canopy polygon (outside polygon) and had its canopy classified as shaded. The process steps are described in Figure 2.

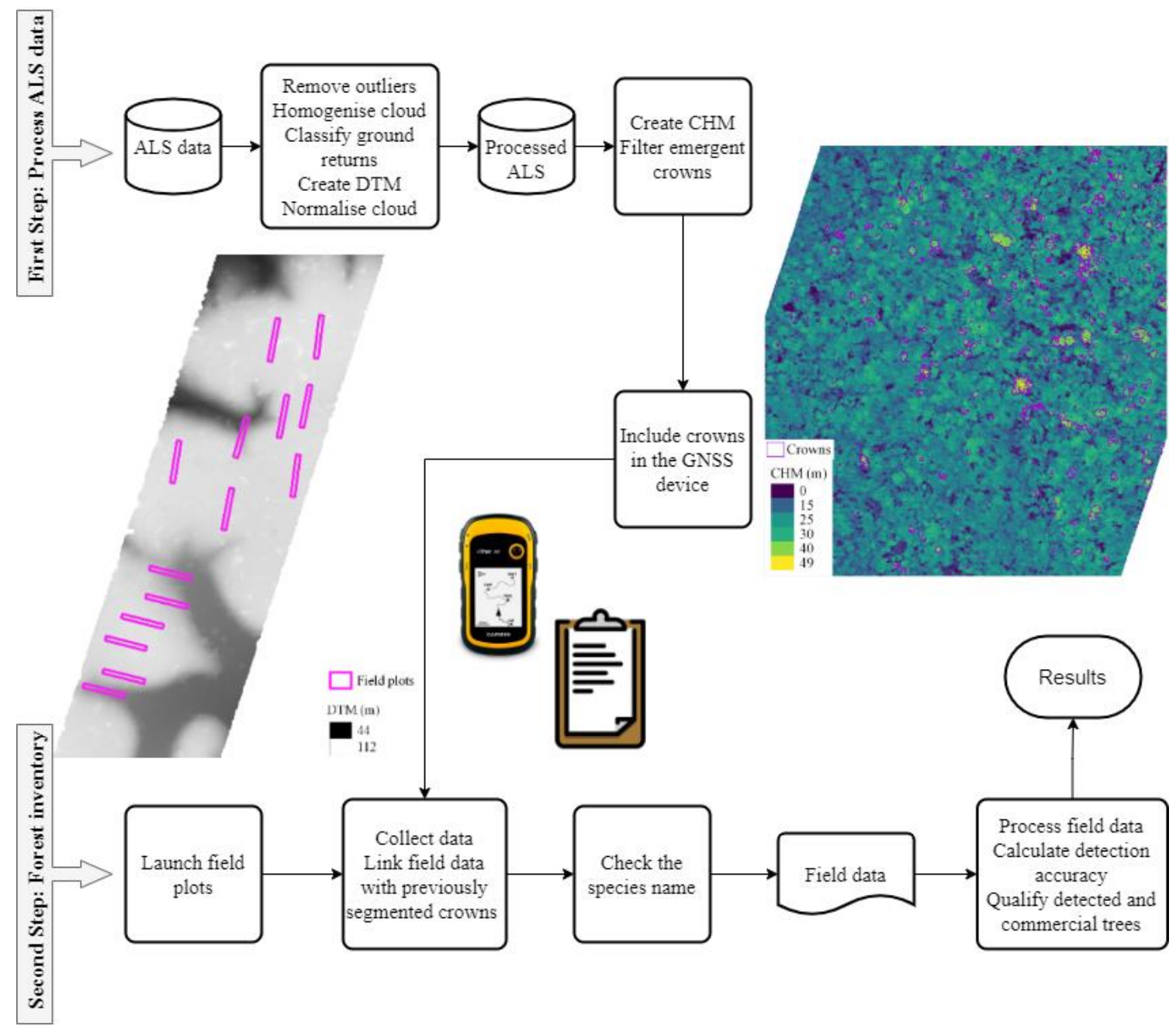

Figure 2. Methodological flowchart describing the methodology steps.

Considering the confusion matrix, we calculated for each plot the detection rate (recall, $r$, Equation (1)) and the correct detection of the trees (precision, $p$, Equation (2)). 
These two indices were used to obtain the F-score (Equation (3)), which is the overall accuracy taking into account both commission and omission errors [60].

$$
\begin{gathered}
r=\frac{I I}{(I I+I S)} \\
p=\frac{I I}{(I I+O I)} \\
F-\text { score }=2 x \frac{r \times p}{(r+p)}
\end{gathered}
$$

To qualify what has been detected from ALS, we analyzed the characteristics that influence tree detection. The binomial logistic regression (Equation (4)) was used to evaluate the significance of factors in the detection performance by the ALS. We created a binary variable considering the detected and non-detected trees as 0 and 1 , respectively. In sequence, we fitted a generalized linear model with a logistic link using the binary variables as a function of tree characteristics (stem quality—cif, commercial — com, and sociological position - $s p$ ) and toposequence (topo). We chose the model based on the significance of the parameters $(p$-valor $\leq 0.05)$ and the Akaike Information Criteria (AIC).

$$
\log _{e}\left[\frac{P}{1-P}\right]=\operatorname{logit}(P)=\beta_{0}+\beta_{1} \text { cif }+\beta_{2} \text { com }+\beta_{3} s p+\beta_{4} \text { topo }
$$

where $\operatorname{logit}(p)$ is the odds ratio, $p$ is the probability of finding a tree, $\beta_{0} \sim \beta_{5}$ are the logistic regression coefficients, cif is the stem quality, com is the commercial species, $s p$ is the sociological position and topo is the toposequence.

\section{Results}

\subsection{Qualification and Quantification of Inventory Trees}

We recorded a total of 338 trees with DBH above $50 \mathrm{~cm}$, distributed in 26 botanical families and 93 species. The most representative families were Fabaceae (67 individuals), Lecythidaceae (47 individuals), Sapotaceae (42 individuals), Apocynaceae (30 individuals) and Vochysiaceae (22 individuals). The most frequent species are Pouteria minima T.D.Penn. (26 individuals), Goupia glabra Aubl. (18 individuals), Aspidosperma marcgravianum Woodson (14 individuals), Piptadenia suaveolens Miq. (13 individuals), Qualea paraensis Ducke (13 individuals) and Geissospermum argenteum Woodson (10 individuals). The structural analysis showed that the species with highest importance values were: Pouteria minima (IVI = 6.52), Goupia glabra (5.15), Qualea paraensis (3.95), Piptadenia suaveolens (3.90), and Aspidosperma marcgravianum (3.89). Additional information is provided in Supplementary Tables S1 and S2.

The emergent crowns (height $>35 \mathrm{~m}$ ) from the ALS canopy height model were linked to $54.44 \%$ of the trees greater than $50 \mathrm{~cm}$ of DBH, recorded in the field. Trees from the climax and intermediary groups were much more predominant among the emergent crowns than trees from the pioneer group: $74 \%$ of intermediary trees and $21 \%$ of climax trees were included in the emergent crowns, while only $3 \%$ were pioneer trees. The remaining $2 \%$ of emergent crowns were related to trees not included in any group (Table 1). 
Table 1. Discrimination of each sociological position regarding the number of individuals by ecological group, presence in the emergent canopy, and commercial interest.

\begin{tabular}{|c|c|c|c|c|}
\hline Ecological Groups & Detected Trees & Not Detected Trees & $\begin{array}{c}\text { Trees with Commercial } \\
\text { Interest }\end{array}$ & Main Species (\# Individuals) \\
\hline Clímax & 39 & 22 & 24 & $\begin{array}{c}\text { Goupia glabra Aubl. (18) } \\
\text { Aspidosperma marcgravianum Woodson (14) } \\
\text { Sacoglottis guianensis Benth (6) } \\
\text { Ladenbergia amazonensis Ducke (5) } \\
\text { Cariniana micrantha Ducke (4) } \\
\text { Hymenolobium sericeum Ducke (4) }\end{array}$ \\
\hline Intermediary & 136 & 118 & 66 & $\begin{array}{c}\text { Pouteria minima T.D.Penn. (26) } \\
\text { Qualea paraensis Ducke (13) } \\
\text { Piptadenia suaveolens Miq. (13) } \\
\text { Geissospermum argenteum Woodson (11) } \\
\text { Couratari stellata A.C.Sm. (9) }\end{array}$ \\
\hline Pioneer & 5 & 9 & 1 & $\begin{array}{c}\text { Trattinnickia peruviana Loes. (8) } \\
\text { Dipteryx magnifica Ducke (2) } \\
\text { Inga gracilifolia Ducke (2) } \\
\text { Eriotheca longipedicellata A.Robyns (1) } \\
\text { Jacaranda copaia D.Don (1) }\end{array}$ \\
\hline Not classified & 4 & 5 & 3 & $\begin{array}{c}\text { Maquira sclerophylla C.C.Berg (2) } \\
\text { Apeiba echinata Gaertn. (1) } \\
\text { Chornelia tenuiflora Diels (1) } \\
\text { Glycydendron amazonicum Ducke (1) } \\
\text { Lacmellea gracilis Markgr. (1) } \\
\text { Duckesia verrucosa Cuatrec. (1) } \\
\text { Vantanea parviflora Lam. (1) } \\
\text { Vantanea sp. (1) }\end{array}$ \\
\hline Total & 184 & 154 & 94 & \\
\hline
\end{tabular}

\subsection{Quantification of Trees with Potential for Logging}

Of the 338 trees recorded in the field plots, $28 \%$ (94 individuals) are included in the commercial interest list (Table 2). Goupia glabra and Piptadenia suaveolens were the commercial species with a greater number of individuals (13 and 12 trees, respectively). Of the commercial trees, $70 \%$ (66 individuals within 17 species) were present in the ALS canopy height model. Of the detected trees with commercial interest, $88 \%$ had stems classified in the good (i.e., straight, cylindrical and undamaged) or medium quality (slightly tortuous) class (Table 2).

Table 2. Discrimination of the commercial trees recorded in the field plots.

\begin{tabular}{|c|c|c|c|c|}
\hline & Individuals & Stem Quality & Canopy Illumination & Main Species (\# Individuals) \\
\hline Detected & 66 & $\begin{array}{l}\text { Good: } 37 \\
\text { Medium: } 21 \\
\text { Low: } 8\end{array}$ & $\begin{array}{l}\text { Illuminated: } 61 \\
\text { Partially: } 4 \\
\text { Shaded: } 1\end{array}$ & $\begin{array}{c}\text { Goupia glabra (13) } \\
\text { Piptadenia suaveolens (12) } \\
\text { Qualea paraensis (8) } \\
\text { Couratari stellata (6) } \\
\text { Dinizia excelsa (5) }\end{array}$ \\
\hline Not detected & 28 & $\begin{array}{l}\text { Good: } 10 \\
\text { Medium: } 9 \\
\text { Low: } 9\end{array}$ & $\begin{array}{l}\text { Illuminated: } 20 \\
\text { Partially: } 7 \\
\text { Shaded: } 1\end{array}$ & $\begin{array}{c}\text { Goupia glabra (5) } \\
\text { Qualea paraensis (5) } \\
\text { Clarisia racemosa (3) } \\
\text { Couratari stellata (3) } \\
\text { Ocotea fragrantissima (3) }\end{array}$ \\
\hline
\end{tabular}

\# represents individual numbers. 


\subsection{Characteristics Influencing the Tree Detection Rate from ALS Emergent Crowns}

We observed a high detection rate in our study $(r$, Table 3$)$, indicating that emergent ALS-derived crown polygons are commonly associated with trees having DBH above $50 \mathrm{~cm}$. In all plots, the detection rate was above $80 \%$. The precision values $(p$, Table 3$)$ indicate the amount of trees having a DBH greater than $50 \mathrm{~cm}$ that are linked to an emergent crown polygon. We found precision rates ranging from 0.27 to 0.81 , with 0.55 on average. Approximately half of trees with DBH above $50 \mathrm{~cm}$ in the forest were not associated with any emergent crowns. The f-score $(f-s c)$ follows the higher variation observed in the $p$, ranging from 0.40 to 0.92 , and an average of 0.70 (Table 3).

Table 3. Tree detection rate $(r)$, precision $(p)$ and accuracy $(f-s c)$ for each inventory plot. II $=$ tree found inside ALS-derived polygon and the canopy partially or totally illuminated, $\mathrm{OI}=$ tree outside ALS polygon and canopy partially or totally illuminated and IS = tree inside ALS polygon and shaded canopy.

\begin{tabular}{ccccccc}
\hline Plots & II & OI & IS & $r$ & $p$ & $f$-sc \\
\hline 1 & 6 & 6 & 0 & 1.00 & 0.46 & 0.63 \\
3 & 4 & 11 & 0 & 1.00 & 0.25 & 0.40 \\
7 & 11 & 2 & 0 & 1.00 & 0.85 & 0.92 \\
8 & 6 & 3 & 0 & 1.00 & 0.67 & 0.80 \\
10 & 10 & 6 & 0 & 1.00 & 0.63 & 0.77 \\
11 & 4 & 9 & 0 & 1.00 & 0.31 & 0.47 \\
14 & 13 & 4 & 1 & 0.93 & 0.76 & 0.84 \\
15 & 5 & 19 & 0 & 1.00 & 0.21 & 0.34 \\
16 & 16 & 1 & 2 & 0.89 & 0.94 & 0.91 \\
17 & 10 & 6 & 0 & 1.00 & 0.63 & 0.77 \\
18 & 11 & 7 & 0 & 1.00 & 0.61 & 0.76 \\
19 & 13 & 5 & 2 & 0.87 & 0.72 & 0.79 \\
23 & 6 & 12 & 0 & 1.00 & 0.33 & 0.50 \\
25 & 10 & 10 & 1 & 0.91 & 0.50 & 0.65 \\
26 & 10 & 7 & 0 & 1.00 & 0.59 & 0.74 \\
27 & 6 & 12 & 0 & 1.00 & 0.33 & 0.50 \\
28 & 13 & 3 & 0 & 1.00 & 0.81 & 0.90 \\
29 & 8 & 5 & 0 & 1.00 & 0.61 & 0.76 \\
30 & 9 & 6 & 1 & 0.90 & 0.60 & 0.72 \\
31 & 6 & 7 & 0 & 1.00 & 0.46 & 0.63 \\
\hline General & 177 & 143 & 7 & 0.96 & 0.55 & 0.70 \\
\hline
\end{tabular}

The full model (Equation (4)-AIC $=303.5$ ) had the predictor variables $s p$ and topo nonsignificant ( $p$-value $\geq 0.05$ ). Therefore, we ran the model only for the remaining significant variables (cif and com, AIC $=302.1$ ), which had the coefficients with $p$-values $<0.001{ }^{(* * *}$ ) for stem quality (cif) and $<0.01\left({ }^{* *}\right)$ for species with commercial interest (com). The bracket numbers in model 5 are the standard error.

Probability of detecting trees $=1.1026_{( \pm 0.3325)}^{* * *}-0.7107_{( \pm 0.1751)}^{* * *}$ cif $+\cdots 1.0337_{( \pm 0.3227)}^{* *}$ com

A tree with stem quality classified as good (straight, cylindrical and undamaged) and with commercial interest had a greater probability of being identified in the emergent crown model. The sociological position and the toposequence (valleys and plateaus) did not influence ( $p$-value $>0.05$ ) the odds of trees having a detectable emergent crown in the ALS-CHM.

\section{Discussion}

Our results showed that in an area of $8 \mathrm{ha}, 28 \%$ of the trees greater than $50 \mathrm{~cm}$ (in $\mathrm{DBH}$ ) had commercial interest, and $70 \%$ of these were detected and could therefore be classified in the emergent ALS canopy height model. The number of commercial trees detected in the canopy height model correlated to more than seven trees per hectare, which 
is sufficient to build an SFM plan around [16]. In comparison, [5] analyzed an inventory in the $100 \%$ (census) of 1253 ha and arrived at a density of 10.21 commercial trees per hectare with DBH ranging from 50 to $248 \mathrm{~cm}$.

Our study indicated some factors that influence the odds of a tree being part of the emergent canopy. Characteristics like stem quality and species with commercial interest positively increase the odds. The sociological position and the toposequence (valleys and plateaus) did not significantly influence emergent crowns detection. Desired characteristics for logging among commercial species (cylindrical stems, straight or with a slight tortuosity and undamaged) positively influence their possession of an emergent crown (and therefore potential for detection using ALS). Competition for the resources that permit growth is a key factor in allowing trees to emerge from the mean canopy [44]. Our results highlight that good-quality stems reflect more highly competitive individuals which have crucial characteristics enabling them to surpass the others in height growth.

Basing the operational planning on ALS data can reduce costs, accelerate evaluation and approval by the authorities, and increase transparency and governance. However, we clearly show that field data are still needed. Therefore, we propose the use of ALS detected emergent trees to more efficiently target the field work. Before the necessity of sending field surveyors into the forest, using ALS, in addition to detecting the target trees, it would be possible to optimize the extraction route, avoid steep terrain and costly topographic regions $[3,25,61]$. Instead of doing a census to record all the trees greater than $50 \mathrm{~cm} \mathrm{DBH}$, the field collection will be oriented on the information extracted from ALS data.

Other authors have shown ALS data to enable forest stratification which led to a reduction of $41 \%$ in the required sampling intensity [24]. This significant reduction in sampling units (from 46 to $27-1$ ha plots) saved US $\$ 28,500.00$ by reducing the field work, which paid for the ALS data collection (US \$26,400.00) [24]. We believe that following the approach that reduces sampling intensity [24] with the approach proposed in this paper could be a future object of study. We also encourage similar studies to ours in different areas to enable the f-score comparison.

The ALS data can support the operational plan with much more information than an operational plan based only on field data. Previous work has shown that ALS can be used to monitor logging impact activities $[10,15,16,29]$ and to estimate biomass and carbon changes [18,62]. To avoid expensive multitemporal ALS to monitor and inspect how forests recover after being submitted to logging, this could be combined with a cheaper remote sensing system, such as 3D UAV photogrammetry [63]. Another product that has been widely used is the detection and segmentation of trees [22]; however, it still presents some difficulties, such as species identification [37] and individual crown isolation in dense tropical forests [22], which still makes field work mandatory to obtain this information. With the advances of remote sensing techniques, such as combining ALS with hyperspectral data can help to better segment and detect trees, and maybe enable species identification.

\section{Conclusions}

Using airborne laser scanning can improve SFM planning, reducing field work in the initial stages of planning and additionally adding value to later operational implementation stages. There is no doubt that SFM could benefit from new technologies to make forest management more efficient and less costly, increasing its sustainability. In this paper, we showed that inclusion of emergent trees detected by ALS can be an alternative to the necessity of conducting a full census, resulting in a sufficient number of trees to integrate into an SFM plan, adding transparency, consistency and confidence.

Supplementary Materials: The following are available online at https:/ / www.mdpi.com/article/ 10.3390/f12121724/s1, Table S1: Family and species list recorded in the Experimental Station for Tropical Silviculture, Table S2: Horizontal structural analysis performed for the species recorded in the Experimental Station for Tropical Silviculture. 
Author Contributions: E.B.G. conceived the ideas; E.B.G., C.R.R., D.R.A.d.A. and J.R. designed methodology and collected field data; J.O. provided the "Improving Biomass Estimation Methods for the Amazon" LiDAR data; C.R.R. and E.B.G. analysed the data; C.R.R., E.B.G. and D.R.A.d.A. led the writing of the manuscript, in close collaboration with C.H.S.C., J.R., E.B.G., A.L., N.H., J.O., R.C.S. and L.C.E.R. All authors have read and agreed to the published version of the manuscript.

Funding: Fundo Amazonia, Grant/Award Number: 14.2.0929.1; US Agency for International Development, Grant/Award Number: AID-OAA-A-11-00012. CNPq Universal 403297/2016-8. CNPq Bolsista Produtividade em pesquisa 301661/2019-7.

Data Availability Statement: Not applicable.

Acknowledgments: This work was supported by the Coordenação de Aperfeiçoamento de Pessoal de Nível Superior-Brasil-CAPES-Finance Code 001, Universidade Federal dos Vales do Jequitinhonha e Mucuri (UFVJM), Fundação de Amparo à Pesquisa do Estado de Minas Gerais (FAPEMIG), University of São Paulo (USP/ESALQ), National Institute for Space Research (INPE), National Institute for Amazon Research (INPA) and Amazon Fund (grant 14.2.0929.1). DRAA was supported by the São Paulo Research Foundation (\# 2018/21338-3). EBG is supported by The Brazilian National Council for Scientific and Technological Development (CNPq) (\# 301661/2019-7). JR is funded by Royal Society University Research Fellowship UF130249 and URF $\backslash R \backslash 191014$, and was supported by CNPq Universal 2016, faixa A, Brasil.

Conflicts of Interest: The authors declare no conflict of interest.

\section{References}

1. Kangas, A.; Maltamo, M. (Eds.) Forest Inventory: Methodology and Applications; Springer Science \& Business Media: Berlin/Heidelberg, Germany, 2006.

2. Leckie, D.; Gillis, M. Forest Inventory in Canada with Emphasis on Map Production. For. Chron. 1995, 71, 74-88. [CrossRef]

3. Görgens, E.B.; Mund, J.P.; Cremer, T.; de Conto, T.; Krause, S.; Valbuena, R.; Rodriguez, L.C.E. Automated operational logging plan considering multi-criteria optimization. Comput. Electron. Agric. 2020, 170, 105253. [CrossRef]

4. $\quad$ Longo, M.; Saatchi, S.; Keller, M.; Bowman, K.; Ferraz, A.; Moorcroft, P.R.; Morton, D.C.; Bonal, D.; Brando, P.; Burban, B.; et al. Impacts of degradation on water, energy, and carbon cycling of the Amazon tropical forests. J. Geophys. Res. Biogeosci. 2020, 125, e2020JG005677. [CrossRef] [PubMed]

5. Romero, F.; Jacovine, L.; Torres, C.; Ribeiro, S.; Junior, V.D.M.; da Rocha, S.; Romero, R.; Gaspar, R.; Velasquez, S.; Staudhammer, C.; et al. Forest Management with Reduced-Impact Logging in Amazonia: Estimated Aboveground Volume and Carbon in Commercial Tree Species in Managed Forest in Brazil's State of Acre. Forests 2021, 12, 481. [CrossRef]

6. Holmes, T.P.; Blate, G.; Zweede, J.; Pereira, R.; Barreto, P.; Boltz, F. Custos e Benefícios Financeiros da Exploração Florestal de Impacto Reduzido em Comparação à Exploração Florestal Convencional na Amazônia Oriental, 2nd ed.; Fundação Floresta Tropical: Belém, Brazil, 2002; 66p.

7. Castro, T.N. Comparação de Diferentes Formas de Colheita Florestal na Amazônia Brasileira Através da Modelagem da Produção e do Crescimento. Master's Thesis, Escola Superior de Agricultura “ Luiz de Queiroz"/Universidade de São Paulo, Piracicaba, Brazil, 2012.

8. Medjibe, V.P.; Putz, F.E. Cost comparisons of reduced-impact and conventional logging in the tropics. J. For. Econ. 2012, 18, 242-256. [CrossRef]

9. Silva, J.C.; de Almeida, A.N.; Souza, R.P. Análise estratégica do manejo florestal na Amazônia brasileira. Floresta 2014, 44, 341-348. [CrossRef]

10. d'Oliveira, M.V.; Reutebuch, S.E.; McGaughey, R.J.; Andersen, H.E. Estimating forest biomass and identifying low-intensity logging areas using airborne scanning lidar in Antimary State Forest, Acre State, Western Brazilian Amazon. Remote Sens. Environ. 2012, 124, 479-491. [CrossRef]

11. Costa, F.V.; Costa, F.R.; Magnusson, W.E.; Franklin, E.; Zuanon, J.; Cintra, R.; Luizão, F.; Camargo, J.L.C.; Andrade, A.; Laurance, W.F.; et al. Synthesis of the first 10 years of long-term ecological research in Amazonian Forest ecosystem-implications for conservation and management. Nat. Conserv. 2015, 13, 3-14. [CrossRef]

12. Vidal, E.; West, T.A.; Putz, F.E. Recovery of biomass and merchantable timber volumes twenty years after conventional and reduced-impact logging in Amazonian Brazil. For. Ecol. Manag. 2016, 376, 1-8. [CrossRef]

13. Martha Junior, G.B.; Contini, E.; Navarro, Z. Caracterização da Amazônia Legal e Macrotendências do Ambiente Externo. Embrapa Estudos e Capacitação-Documentos. INFOTECA-E, 2011. Available online: http:/ / www.infoteca.cnptia.embrapa.br/ infoteca/handle/doc/907075 (accessed on 13 July 2021).

14. Andersen, H.E.; Reutebuch, S.E.; McGaughey, R.J.; d'Oliveira, M.V.; Keller, M. Monitoring selective logging in western Amazonia with repeat lidar flights. Remote Sens. Environ. 2014, 151, 157-165. [CrossRef]

15. Pinagé, E.R.; Keller, M.; Duffy, P.; Longo, M.; dos Santos, M.N.; Morton, D.C. Long-Term Impacts of Selective Logging on Amazon Forest Dynamics from Multi-Temporal Airborne LiDAR. Remote Sens. 2019, 11, 709. [CrossRef] 
16. Costa, V.A.M.; Oliveira, A.F.; Santos, J.G.; Bovo, A.A.A.; Almeida, D.R.A.; Gorgens, E.B. Assessing the utility of airborne laser scanning derived indicators for tropical forest management. South. For. J. For. Sci. 2020, 82, 352-358. [CrossRef]

17. Baccini, A.; Goetz, S.; Walker, W.S.; Laporte, N.T.; Sun, M.; Sulla-Menashe, D.; Hackler, J.L.; A Beck, P.S.; O Dubayah, R.; A Friedl, M.; et al. Estimated carbon dioxide emissions from tropical deforestation improved by carbon-density maps. Nat. Clim. Chang. 2012, 2, 182-185. [CrossRef]

18. Longo, M.; Keller, M.; Dos-Santos, M.N.; Leitold, V.; Pinagé, E.R.; Baccini, A.; Saatchi, S.; Nogueira, E.M.; Batistella, M.; Morton, D.C. Aboveground biomass variability across intact and degraded forests in the Brazilian Amazon. Glob. Biogeochem. Cycles 2016, 30, 1639-1660. [CrossRef]

19. Ferraz, A.; Saatchi, S.; Mallet, C.; Meyer, V. Lidar detection of individual tree size in tropical forests. Remote Sens. Environ. 2016, 183, 318-333. [CrossRef]

20. Figueiredo, E.O.; d'Oliveira, M.V.N.; Braz, E.M.; de Almeida Papa, D.; Fearnside, P.M. LIDAR-based estimation of bole biomass for precision management of an Amazonian forest: Comparisons of ground-based and remotely sensed estimates. Remote Sens. Environ. 2016, 187, 281-293. [CrossRef]

21. Dalponte, M.; Frizzera, L.; Gianelle, D. Individual tree crown delineation and tree species classification with hyperspectral and LiDAR data. PeerJ 2019, 6, e6227. [CrossRef]

22. Coomes, D.A.; Dalponte, M.; Jucker, T.; Asner, G.P.; Banin, L.F.; Burslem, D.; Lewis, S.L.; Nilus, R.; Phillips, O.; Phua, M.-H.; et al. Area-based vs tree-centric approaches to mapping forest carbon in Southeast Asian forests from airborne laser scanning data. Remote Sens. Environ. 2017, 194, 77-88. [CrossRef]

23. Wulder, M.A.; Bater, C.W.; Coops, N.C.; Hilker, T.; White, J.C. The role of LiDAR in sustainable forest management. For. Chron. 2008, 84, 807-826. [CrossRef]

24. Papa, D.D.A.; de Almeida, D.R.A.; Silva, C.A.; Figueiredo, E.O.; Stark, S.C.; Valbuena, R.; Rodriguez, L.C.E.; Oliveira, M.V.N.D. Evaluating tropical forest classification and field sampling stratification from LiDAR to reduce effort and enable landscape monitoring. For. Ecol. Manag. 2020, 457, 117634. [CrossRef]

25. Andrade, M.S.; Gorgens, E.B.; Reis, C.R.; Cantinho, R.Z.; Assis, M.; Sato, L.; Ometto, J.P.H.B. Airborne laser scanning for terrain modeling in the Amazon forest. Acta Amaz. 2018, 48, 271-279. [CrossRef]

26. Murphy, P.N.; Ogilvie, J.; Meng, F.R.; Arp, P. Stream network modelling using lidar and photogrammetric digital elevation models: A comparison and field verification. Hydrol. Process. Int. J. 2008, 22, 1747-1754. [CrossRef]

27. Görgens, E.B.; Soares, C.P.; Nunes, M.H.; Rodriguez, L.C. Characterization of Brazilian forest types utilizing canopy height profiles derived from airborne laser scanning. Appl. Veg. Sci. 2016, 19, 518-527. [CrossRef]

28. Dalagnol, R.; Wagner, F.H.; Galvão, L.S.; Streher, A.S.; Phillips, O.L.; Gloor, E.; Pugh, T.A.M.; Ometto, J.P.H.B.; Aragão, L.E.O.C. Large-scale variations in the dynamics of Amazon forest canopy gaps from airborne lidar data and opportunities for tree mortality estimates. Sci. Rep. 2021, 11, 1-14. [CrossRef]

29. Reis, C.R.; Jackson, T.D.; Gorgens, E.B.; Dalagnol, R.; Jucker, T.; Nunes, M.H.; Ometto, J.P.; Aragão, L.E.O.C.; Rodriguez, L.C.E.; Coomes, D.A. Forest structure and degradation drive canopy gap sizes across the Brazilian Amazon. Biorxiv Prepr. Serv. Biol. 2021. [CrossRef]

30. de Almeida, D.R.A.; Stark, S.C.; Shao, G.; Schietti, J.; Nelson, B.W.; Silva, C.A.; Gorgens, E.B.; Valbuena, R.; Papa, D.D.A.; Brancalion, P.H.S. Optimizing the remote detection of tropical rainforest structure with airborne lidar: Leaf area profile sensitivity to pulse density and spatial sampling. Remote Sens. 2019, 11, 92. [CrossRef]

31. Wedeux, B.M.M.; Coomes, D.A. Landscape-scale changes in forest canopy structure across a partially logged tropical peat swamp. Biogeosciences 2015, 12, 6707-6719. [CrossRef]

32. Nunes, M.H.; Jucker, T.; Riutta, T.; Svátek, M.; Kvasnica, J.; Rejžek, M.; Matula, R.; Majalap, N.; Ewers, R.M.; Swinfield, T.; et al. Recovery of logged forest fragments in a human-modified tropical landscape during the 2015-16 El Niño. Nat. Commun. 2021, 12, 1526. [CrossRef]

33. Lefsky, M.A.; Cohen, W.B.; Acker, S.A.; Parker, G.G.; Spies, T.A.; Harding, D. Lidar remote sensing of the canopy structure and biophysical properties of Douglas-fir western hemlock forests. Remote Sens. Environ. 1999, 70, 339-361. [CrossRef]

34. Bater, C.W.; Coops, N.C.; Gergel, S.E.; Goodwin, N.R. Towards the estimation of tree structural class in northwest coastal forests using lidar remote sensing. Proc. ISPRS Workshop Laser Scanning 2007, 36, 38-43.

35. Stark, S.C.; Enquist, B.; Saleska, S.R.; Leitold, V.; Schietti, J.; Longo, M.; Alves, L.; de Camargo, P.B.; Oliveira, R.C. Linking canopy leaf area and light environments with tree size distributions to explain Amazon forest demography. Ecol. Lett. 2015, 18, 636-645. [CrossRef] [PubMed]

36. Suárez, J.; Ontiveros, C.; Smith, S.; Snape, S. Use of airborne LiDAR and aerial photography in the estimation of individual tree heights in forestry. Comput. Geosci. 2005, 31, 253-262. [CrossRef]

37. Broadbent, E.N.; Asner, G.P.; Keller, M.; Knapp, D.E.; Oliveira, P.J.C.; Silva, J.N. Forest fragmentation and edge effects from deforestation and selective logging in the Brazilian Amazon. Biol. Conserv. 2008, 141, 1745-1757. [CrossRef]

38. Amaral, M.R.; Lima, A.J.; Higuchi, F.G.; dos Santos, J.; Higuchi, N. Dynamics of tropical forest twenty-five years after experimental logging in Central Amazon mature forest. Forests 2019, 10, 89. [CrossRef]

39. Nascimento, R.G.M.; do Amaral Machado, S.; Figueiredo Filho, A.; Higuchi, N. Using diameter variation index of pioneer species for classification and modeling tropical forest yield. BIOFIX Sci. J. 2016, 1(1), 83-96. [CrossRef] 
40. Alvares, C.A.; Stape, J.L.; Sentelhas, P.C.; Gonçalves, J.D.M.; Sparovek, G. Köppen's climate classification map for Brazil. Meteorol. Z. 2013, 22, 711-728. [CrossRef]

41. Ometto, J.P.; Gorgens, E.B.; Assis, M.; Cantinho, R.Z.; Pereira, F.R.S.; Sato, L.Y. L3A—Airborne LiDAR transects summary collected by EBA in the Brazilian Amazon (Version 20210616) [Data set]. Zenodo 2021. [CrossRef]

42. de Almeida, C.T.; Galvão, L.S.; de Oliveira Cruz e Aragão, L.E.; Ometto, J.P.H.B.; Jacon, A.D.; de Souza Pereira, F.R.; Sato, L.Y.; Pontes-Lopes, A.; Graça, P.; Silva, C.V.D.J.; et al. Combining LiDAR and hyperspectral data for aboveground biomass modeling in the Brazilian Amazon using different regression algorithms. Remote Sens. Environ. 2019, 232, 111323. [CrossRef]

43. Gorgens, E.B.; Motta, A.Z.; Assis, M.; Nunes, M.; Jackson, T.; Coomes, D.; Rosette, J.; Aragão, L.E.O.E.C.; Ometto, J. The giant trees of the Amazon basin. Front. Ecol. Environ. 2019, 17, 373-374. [CrossRef]

44. Gorgens, E.B.; Nunes, M.; Jackson, T.; Coomes, D.; Keller, M.; Reis, C.; Valbuena, R.; Rosette, J.; De Almeida, D.R.A.; Gimenez, B.; et al. Resource availability and disturbance shape maximum tree height across the Amazon. Glob. Chang. Biol. 2020, 27, 177-189. [CrossRef]

45. Tejada, G.; Gorgens, E.B.; Espírito-Santo, F.D.B.; Cantinho, R.Z.; Ometto, J.P. Evaluating spatial coverage of data on the aboveground biomass in undisturbed forests in the Brazilian Amazon. Carbon Balance Manag. 2019, 14, 1-18. [CrossRef] [PubMed]

46. Mcgaughey, R.J.M. FUSION/LDV. Software for LIDAR Data Analysis and Visualization. 2018. Available online: http:/ / forsys.cfr. washington.edu/FUSION/fusion_overview.html (accessed on 20 March 2018).

47. Kraus, K.; Pfeifer, N. Determination of terrain models in wooded areas with airborne laser scanner data. ISPRS J. Photogramm. Remote Sens. 1998, 53, 193-203. [CrossRef]

48. Kraus, K.; Pfeifer, N. Advanced Dtm Generation From Lidar Data. Int. Arch. Photogramm. Remote Sens. 2001, XXXIV, $22-24$.

49. Popescu, S.C.; Wynne, R.H. Seeing the trees in the forest: Using lidar and multispectral data fusion with local filtering and variable window size for estimating tree height. Photogramm. Eng. Remote Sens. 2004, 70, 589-604. [CrossRef]

50. CONAMA, Conselho Nacional do Meio Ambiente. Resolução no 406, de 02 de Fevereiro de 2009. Estabelece Parâmetros Técnicos a Serem Adotados na Elaboração, Apresentação, Avaliação Técnica e Execução de PLANO de Manejo Florestal Sustentável-PMFS com Fins Madeireiros, para Florestas Nativas e suas Formas de Sucessão no Bioma Amazônia. Available online: http:/ / www.mma.gov.br/port/conama/legiabre.cfm?codlegi=597 (accessed on 3 November 2019).

51. Carneiro, V.M.C. Composição Florística e Análise Estrutural da Floresta Primária de Terra Firme na Bacia do rio Cuieiras, Manaus-Am. Master's Thesis, Instituto Nacional de Pesquisas da Amazônia, Manaus, Brazil, 2004.

52. Lima, A.J.N. Avaliação de um Sistema de Inventário Florestal Contínuo em Áreas Manejadas e não Manejadas do Estado do Amazonas (AM). Ph.D. Thesis, Instituto Nacional de Pesquisas da Amazônia, Manaus, Brazil, 2010.

53. Serafini, R.T. Estrutura de Fragmentos Florestais Urbanos de Manaus-AM: Implicações para seu Manejo e Conservação. Master's Thesis, Instituto Nacional de Pesquisas da Amazônia, Manaus, Brazil, 2007.

54. Roth, P.; Miranda, P.N.; Monteiro, E.P.; Oliveira, R.S. Manual do Técnico Florestal. Rio Branco, AC; Design Gráfico Guilherme K. Noronha: Rio Branco, Brazil, 2009; 260p.

55. Valbuena, R.; Mauro, F.; Suárez, R.R.S.; Manzanera, J.A. Accuracy and precision of GPS receivers under forest canopies in a mountainous environment. Span. J. Agric. Res. 2010, 4, 1047-1057. [CrossRef]

56. Valbuena, R.; Mauro, F.; Rodríguez-Solano, R.; Manzanera, J.A. Partial least squares for discriminating variance components in global navigation satellite systems accuracy obtained under scots pine canopies. For. Sci. 2012, 58, 139-153. [CrossRef]

57. Mourão, G.H.O. Distribuição Espacial de Árvores Emergentes na Amazônia a Partir de Dados Oriundos de Escaneamento Laser Aerotransportado. Master's Thesis, Universidade Federal dos Vales do Jequitinhonha e Mucuri, Diamantina, Brazil, 2021.

58. Lira, L.P. Agrupamento Ecológico e Funcional de Espécies Florestais da Amazônia Central. Master's Thesis, Universidade Federal do Amazonas, Manaus, Brazil, 2011.

59. Braga, S.R.; Gorgens, E.B.; de Oliveira, M.L.R. Inventário de Nativas: Aplicativo Shiny para Processamento de Inventário de Florestas Nativas, 2017. Available online: https:/ / sites.google.com/view/forestsuite/home (accessed on 31 March 2021).

60. Li, W.; Guo, Q.; Jakubowski, M.K.; Kelly, M. A new method for segmenting individual trees from the lidar point cloud. Photogramm. Eng. Remote Sens. 2012, 78, 75-84. [CrossRef]

61. Barbosa, R.P.; Rodriguez, L.C.E.; Gorgens, E.B. Otimização multicritério da extração madeireira na Amazônia com o uso de escaneamento laser aerotransportado. Sci. For. 2017, 45, 541-550. [CrossRef]

62. Hunter, M.O.; Keller, M.; Morton, D.; Cook, B.; Lefsky, M.; Ducey, M.; Saleska, S.; de Oliveira, R.C., Jr.; Schietti, J. Structural Dynamics of Tropical Moist Forest Gaps. PLoS ONE 2015, 10, e0132144. [CrossRef]

63. D’Oliveira, M.V.N.; Figueiredo, E.O.; de Almeida, D.R.A.; Oliveira, L.C.; Silva, C.A.; Nelson, B.W.; da Cunha, R.M.; Papa, D.D.A.; Stark, S.C.; Valbuena, R. Impacts of selective logging on Amazon forest canopy structure and biomass with a LiDAR and photogrammetric survey sequence. For. Ecol. Manag. 2021, 500, 119648. [CrossRef] 